\title{
Health Education: Bridging the Cap between Knowing and Doing
}

Renate Westphal M.B. B.Ch., D.P.H.

Assistant Medical Officer of Health, City Health Department, Johannesburg

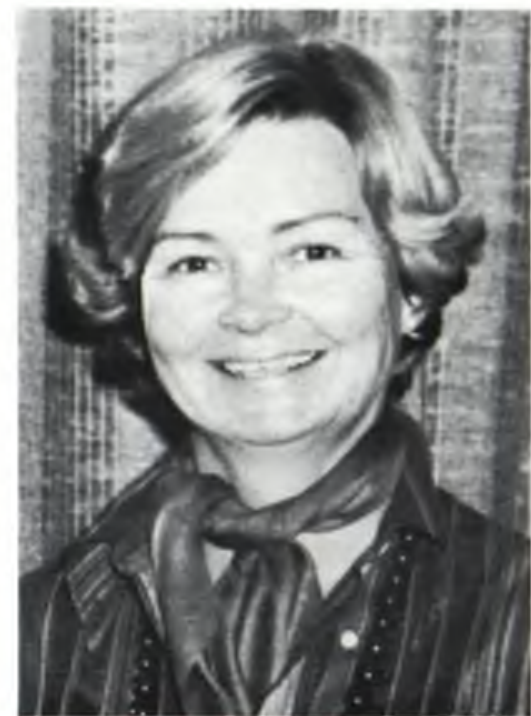

\section{OPSOMMING}

Hierdie artikel gaan hoofsaaklik oor formele gesondheidsvoorligting in vinnig veranderende oorgangstydperke in die sameling.

'n Kort beskry wing word gegee van die veranderingsproses, verwant aan sekere begrippe met betrekking tot gesondheidsvoorligting - gemeenskapsbetrokkenheid, vrywillige gesondheidsvoorligters, groepbesprekings en gemeenskapsleiers.

Die afleiding word gemaak dat, slegs waar die gesondheidwerker, gemeenskapsleiers en lede van die gemeenskap, deel het aan gemeenskaplike belange, 'n gemeenskaplike taal praat en daar 'n onderlinge ooreenkoms is in persoonlike- en sosiale karaktereienskappe — die aanvaarding van nuwe begrippe 'n meer blywende uitwerking tot gevolg het ten opsigte van die verbreding van kennis, houdingsvorming en verandering in openbare optrede.

\section{"Changing people's customs is an even more delicate process than surgery"}

Edward H. Spicer (1952)

$\mathbf{T}$ HE aim of health education is to influence or even change behaviour affecting people's health. It must at all times be intrinsically valuable and worthwhile. Many aspects of health behaviour are part of man's normal everyday life, other aspects however, require conscious efforts based on knowledge. All aspects are directed towards preserving health and avoiding illness.

Leo Baric (1972) —2 describes two concepts of health education, the first one denoting the contents (health) and the second one the process (education). He then defines health education as two separate (but often parallel) processes:Informal health education, considered to be concerned with transmitting knowledge about health and disease as a planned process.

\section{INFORMAL HEALTH EDUCATION}

Informal health is part of an evolutionary process which involves the transmission from one generation to another, or from one peer to another, of RELEVANT health information based on accumulated empirical knowledge. This is mostly 
learnt in the family, the home and the community. Empirical knowledge of one generation or peer group, if shared by most people, can become part of 'normal' behaviour for future generations

\section{FORMAL HEALTH EDUCATION}

Formal health education, in transmitting knowledge to one generation can influence informal health education of the next, creating new 'normal' ways of dealing with healthrelated problems. In our western society, accumulation and updating of medical knowledge has been entrusted to the medical profession. who can carry out this activity directly in the health care delivery system or indirectly by initiating health education services in the homes, schools and other community groups. Formal health education is usually initiated by health professionals and aims to influence attitudes and practices related to individual, family and community health. Health knowledge is mainly gained in schools, in the health care delivery system and from the media from a wide range of professional workers. Most health education programmes are formally constructed and provide information about health threats and desired behaviour changes.

This paper is mainly concerned with formal health education in rapidly changing transitional societies, where new and rational decisions regarding health behaviour have to be made by families and communities living in their new environment, and, where innovative decision-making has to take place, where new ideas need to replace some of the old ones, and where new alternatives must be wisely chosen.

I intend describing certain theoretical aspects basic to modern health education taken from communication and educational theory. I have applied these to concepts we so commonly hear - community involvement, grass-root workers, group discussion, and community leaders.

\section{THE INNOVATION PROCESS}

For people to learn to practise new health behaviours, a certain period of time has to pass - from the first knowledge of an innovation to the decision to adopt or reject it.

Basically there are several stages. People hear and then become aware of the existence of a new idea but they do not yet have any information on it. They become interested and may actively seek further information, which they will evaluate by applying the idea to their present and possibly future life situation. Then they will decide whether they will or will not try it. Usually people will preliminarily apply the new idea on a small scale or for a short time to see if it is of use. Ultimately they will decide to either continually use it on a full scale or totally to reject it.

Generally people tend to expose themselves to those ideas which are in accord with their interests, needs and existing attitudes. Individuals need to perceive the innovation relevant to their needs, attitudes and beliefs. People with little education are often still more deeply rooted in their traditional attitudes and values, and stand a greater chance not to perceive new ideas. What is more, later they tend to discontinue a health practice they had temporarily adopted.

Shoemaker (1976) — 3 describes four stages in the innovation process:

\section{KNOWLEDGE -}

A stage of cognitive thinking, where the individual has gained new knowledge from the mass media or in his daily contact with others, and where he gains some understanding of how the new idea functions. It is at this stage that people develop perceived needs for an innovation

Shoemaker defines a need as follows:

A need is a state of dissatisfaction or frustration and occurs when one's desires outweigh one's actualities when 'wants" outrun 'gets'.

The problem of whether 'new' knowledge creates an awareness of 'new' needs, or whether felt needs create a desire to seek new knowledge, leads to the question: Which came first - the chicken or the egg?

Often new ideas may not be seen as potentially useful by the individual or may be even irrelevant or not relevant enough for his particular social situation, and therefore of no interest to him at the time.

What is crucially important. is that KNOWING about an idea is often quite different from USING the idea. Professor Ryle (1972) - ${ }^{4}$ distinguished between knowing that and knowing how:

To be intelligent is not merely to satisfy criteria but to apply them.

\section{KNOWING THAT}

Knowing that leads to awareness of an idea and to intelligently grasping the situation. Until one knows about an idea, one cannot start to form an attitude towards it. Once the individual knows about a possible innovation. he may actively seek more information about it. What messages he receives depend on his existing network of concepts. How he interprets the new messages depends on his personality and his norms with his particular social system.

\section{KNOWING HOW}

Knowing how really means putting the prescription or new idea into practice, as Ryle states:

We learn how by practice, schooled indeed by criticism and example, often quite unaided by any lesson in the theory.

Already in $400 \mathrm{BC}$ Sophocles was thinking very similarly when he said:

One must learn by doing the thing. Although you think you know it - you have no certainty until you have tried it.

\section{PERSUASION -}

The individual now forms a favourable or unfavourable attitude towards the innovation. This takes place mainly with interpersonal exchange of ideas and feelings. The individual may feel some risks. He may be unsure of the idea's possible results and feel a need to seek support from his family, peers or a friendly health professional, on a interpersonal basis, in an attempt to confirm his new beliefs.

\section{DECISION -}

The individual now engages in activities which lead to his choice to adopt or to reject the innovation. The individual may decide on his own, but often his decision-making will be facilitated by peer and family group decision-making.

\section{CONFIRMATION -}

The individual seeks reinforcement of the innovation he 
has made. He will seek out interpersonal situations to gain further knowledge and re-confirm his new beliefs and attitudes. He or she will continue to make sure that the decision made is still a good and valuable one.

Let us have a look to see what is important in all this theory. Many of us have experienced patients repeating to us almost word for word how to carry out an instruction. BUT later we find that they did not actually practise in their daily lives what they had been taught. Perhaps we have been concentrating too much on telling, on too much 'knowing that'. and have omitted to really involve ourselves deeply enough with our patients to learn what 'knowing how' means to them.

Accepted and commonly used health practices have over the centuries developed in families and communities, where people and their teachers and innovators were living in daily close contact with each other and knew how their fellow men felt about many particular health matters. As people moved to live in larger and larger urban complexes, and as medical technology developed, doctors and nurses through their long training have moved further and further from their communities. In many cases they do not share attitudes to health practices with their patients any longer. They do not know any more exactly who makes the decisions in the community they serve, and why they are made. Health professionals have had to resort to teaching more and more 'that' and to move further and further away from 'how'.

In recent years this trend is being reversed. We have all become aware of the important role informal health education plays in influencing community health behaviour. We have learnt through bitter experience of non-compliance that new health norms cannot be imposed by us as health professionals.

\section{COMMUNITY INVOLVEMENT}

In this process we set out to involve people in their own development. We educate them to make and carry out decisions which would affect and further their own health status and that of their communities.

Gradually several main strategies evolved. One of these, the use of 'grass-root' workers has been used in many countries with great success. These community health workers live in many cases much closer to their communities than the doctors and nurses in the area, and often take care of their families and themselves in ways which are very similar to those practised by their friends and neighbours. They know the 'how' more intimately than the highly trained nurse or doctor. The modern Health Education motto: 'Every health worker a health educator - from the professor to the ward maid' holds today, as it did before. In many countries, community developing agents have gone into the community to look for volunteers, or paid community workers to enlist their help in closing the gaps between knowing and doing between 'knowing that' and 'knowing how'. These new health care workers are often able to evolve practical and acceptable ways of changing and moulding existing health practices to accommodate new ideas which have become necessary in new and changing environments.

But this is not enough. If people are going to be persuaded to form favourable attitudes to an innovation, they must have many opportunities to discuss this with each other. Again this is nothing new, for people have commonly done this in the past - at the market place when they were shopping, at the wells when they were drawing water and on riverbanks when they were washing their laundry. This is where people tried to confirm their beliefs and to seek support from each other before deciding to accept or reject a new idea. These people in their particular social systems actively participated and were involved in the decision-making process, and thus found it easier to accept new ideas and often felt more satisfied with the innovation once they had accepted it.

Kurt Lewin (1943) _ ${ }^{5}$ illustrated that group discussion methods are much more successful in convincing housewives to adopt new food products

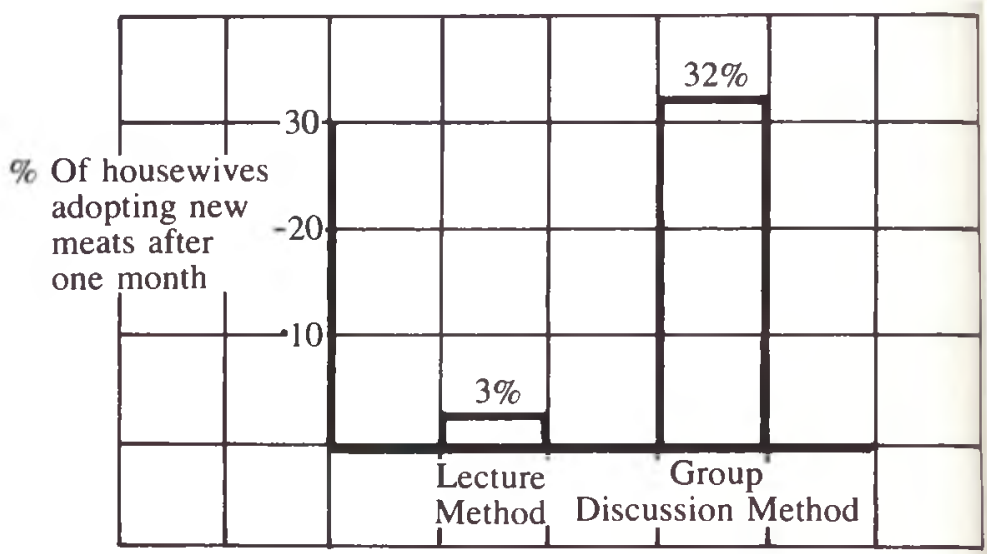

The above diagram illustrates that there is a much higher degree of acceptance of an innovation, when members of the audience are more highly involved in the decision-making process.

Ideally, people themselves should initiate innovation to bring about better standards of living for themselves. But, if there are no such activities spontaneously forthcoming from the community, they can be aroused and stimulated. Doctors and nurses can move into their communities and can together with the leaders define priorities, objectives and desired action. But in large urban areas, where complex collections of groups and sub-groups of people live together, this is not always easy to achieve. Commonly the term 'community' applies to a specific area. One can, however, not assume that because people share a common administrative boundary that they will necessarily share common interests, values and goals. Some sub-groups, however, may share a common goal for a particular purpose.

However, dominant groups, people in positions of leadership or power, in the churches, business and voluntary associations, may well be interested in health problems in their area. The most important factor is this people-to-people contact, to identify persons who are enthusiastic about a particular proposed health activity. This can be achieved by feeding back information to community leaders, by forming joint committees, interest groups or task forces of community leaders and health workers. Ultimately, joint planning committees can be formulated and gradually local men and women, speaking the local language, known and trusted and easily available for consultation, can actively participate in health education.

. education provided to learners must be perceived by them as relevant to their values, concerns, goals, past experiences and present circumstances. If the learner does not have a role in specifying what is and is not 
relevant to his or her lifespace, the likelihood that the educator will be able to design an appropriate or effective plan for influencing the learner's behaviour, is indeed very small.

In the above quotation, Professor Simmons (1977) - 6 actually takes us one step further, when he states that learners have a definite role in specifying what is relevant in their daily lives. This may perhaps apply in the still developing societies more to the community leaders, but ultimately and ideally, must apply to many if not most members of a community. This is the only way to ensure that health education projects fit comfortably into the established order.

John Wakefield (1974) $-{ }^{7}$ stresses that the first moves in planning a health education project are crucial:

The community leaders will want to know to whom, and in what form, and how a health education programme is to be implemented. It must be made clear that the proposals are open to discussion and revision in the light of their advice.

This implies that the community leaders must be consulted right at the start of a new health education programme before we as doctors and nurses have 'decided' what would be good for our community and before we have prescribed to the community and have tried to impose our values upon them. Only then will change be generated from within when needs, expectations, attitudes and behaviour are taken full cognisance of, and can real development commence. In this way, we may be able to develop responsible, active and informed communities.

\section{OPINION LEADERSHIP}

In all societies there are a small number of innovators people who are eager to try a new idea. However, often this interest 'leads them out of their local circle of peers and into a more cosmopolitan social relationship' (Shoemaker $-^{8}$ ). Most innovators show too much venturesomeness to be seen as opinion leaders by their communities. On the other hand, there are the laggards - often people deeply rooted in their particular way of life and thus slow to adopt new and different ideas. In between these two lies a broad spectrum of early and late adoptors of new ideas. Opinion leaders are found amongst the early adoptors - people of great respectability, who are more integrated into the community than the innovators, and who serve as role models for many other members of their social system. Opinion leaders have often received a better education but this is not necessarily so. Usually opinion leaders are technically more competent and are socially available to their community for advice and guidance. Opinion leaders may be trendsetters on one hand, but on the other may be quite traditional.

Even if we have sought out the opinion leaders in a particular community, and have involved them fully in our health education project, we still need to begin with ideas and innovations which possess a high degree of advantage for the people at the time, and which are compatible with existing beliefs. If these considerations are taken into account, a new health education programme has a much higher likelihood of success.

\section{COMMUNICATION CHANNELS}

The nature of the social relationship between two people determines the conditions under which they will tell each other about their new ideas, and further, it influences the effect the telling will have one on the other.
If one wishes to merely inform another person, mass media channels - radio, television, films, newspapers, magazines, and pamphlets - are very useful and often the best method for reaching larger audiences. On the other hand, if one wants to persuade the other person to form a favourable attitude to a new idea, the interpersonal channel of face-to-face interchange is far more effective.

In our health education programs we must therefore allow for both - the formal education and the informal one. We must design our programs in such a manner that people can gain new knowledge about certain health problems AND that they continually have opportunities for discussion - to be persuaded by each other and their health workers in the interpersonal situation. We must also design teaching methods which will facilitate the trials of innovations to make it easier to adopt a new idea. There must be someone on hand to provide continuing support while people are trying to make up their minds. Without this support there is no assurance against discontinuing because of the many negative messages which exist in the individual's social system. Smoking is a classical example of this where both advertisements and peers pressurise the individual to such an extent, that he gives up his innovation.

Late or slow adopters may well accept a new idea, but often they discontinue early because they are disenchanted with the effect or lack of effect of the innovation on their daily way of life

Often laggards merely pay lip service to a new idea and have no intention really of complying with the practice. Sometimes they lack the educational background to comprehend the implication of a proposed innovation. Very often the problem is not really a confusion of values, but the need to reconcile several new values with old existing ones. During this time of consolidation, an individual is likely to drop out of a health programme if he has not had further adequate learning opportunities to strengthen his new convictions.

Where the health workers, the community leaders and the members of the community share common meanings, share a mutual sub-cultural language and are alike in personal and social characteristics, the communication of new ideas is likely to have a lasting effect in terms of gain in knowledge, attitude formation and change in overt behaviour

Every health worker must involve himself with his community, must seek out the opinion leaders and must invite community leaders to participate fully in the planning and decision-making process. If this is not done well and efficiently, an educational project may easily fail. The gap between knowing and doing must be narrowed by taking full cognisance of the importance of both 'knowing that' and 'knowing how'.

\section{BIBLIOGRAPHY}

1. SPICER, E.H. (1952). Human Problems in Technological Change. New York: Russell Sage Foundation.pg 13.

2. BARIC, L.ed (1972). Behavioural Sciences in Health and Disease. Published by the International Joumal of Health Education. pg 20.

3. ROGERS, E.M. \& Shoemaker F.F. Communications of Innovation - A ROGERS, E.M. \& Shoemaker F.F. Communications of In
Cross-cultural Approach. 2nd Ed. The Free Press. New York.

4. RYLE, G. (1949). The Concept of Mind, Harmondsworth: Penguin. pg 28.

5. LEWIN, K. (1943). Group Decision and Social Change. NEWCOMB, Theo dore M. and HARTLEY, Eugene L. Eds. Readings in Social Psychology. New York

6. SIMMONS, J.J. (1977). A.J.P.M. 67, 12, pg 1138

7. WAKEFIELD, G (1974). Community Involvement: Rhetoric or Reality. International Joumat Health Education. XVII Pg 100

8. ROGERS, E.M. \& Shoemaker, F.F. (1976) ibid 